\title{
Secularization in the Holy Land: Challenges for the State- Secularism and Nationalism in Israel
}

\author{
Ann-Kathrin Biewener \\ University of Potsdam, Potsdam, Germany
}

\begin{abstract}
Israel is on the way to become a secular state. Parts of the society are separating from the religious authority. Under the international pressure of the globalization it is getting more important for Israel to integrate in the western interpretation of secularization. It seems that a secular Israel could resolve the political and social inequality between the ethnic groups. But the process of secularization causes a couple of problems in the society. Since years Israel is on the move to find his identity in a pluralistic and globalized world. The religious affiliation is decreasing in Israel. People do not believe privately anymore. In public it is still demonstrated, that Israel is united in the religious beliefs. Nationalism regains strength in Israel and causes new conflicts. This qualitative work based on hermeneutic and media analyses will show how problematic the way of secularization is and that the society will be probably even more unequal than before. If Israel is losing his ties of religious beliefs it needs to find a new identity. But the increase of secularization causes also the increase of nationalism. Nationalism and in his extreme forms of religious nationalism or ethnocentrism will jeopardize equality under the population. Thus, the question has to be answered if a secular Israel will be more open, pluralistic or equal and finally better prepared to meet the challenges of the politically unstable Middle East region and the globalization.
\end{abstract}

Keywords: Israel, Judaism, secularization, ethnicity, nationalism

\section{Introduction}

Israel is known as the Jewish state; therefore it is questionable why to explore secularization in Israel. Religion and especially Judaism has an important impact on society and politics, however Israel has no state religion and follows democratic principles. The majority of the population in Israel belongs to the Jewish culture and religion. Judaism cannot only be seen as religion, but moreover as the main culture of the state which provides the core values of the national identity. For the purpose of this paper it is considered the problematic of the strong connection between religion, politics and society under the circumstances of secularization.

Currently Israel is reaching a crossroad because globalization, immigration and the western influence have an impact on Israeli society. It can be asked if a strong connection between religion and politics is still necessary and accepted under these circumstances. The religious status quo has still a huge impact on the daily life in Israel; marriage, divorce or burring without the rabbinate is impossible and also immigrants have the problem to be recognized as Jews by the orthodox law to grant full citizenship under the law of return. But people do not believe anymore in Judaism as religion, however in public it is still demonstrated as a

Ann-Kathrin Biewener, Ph.D., Department of Public and Nonprofit Management, University of Potsdam. 
national core value. Because the orthodox religious movement has the monopoly over questions of personal status, people are unsatisfied with the current situation of no alternatives to the orthodox offers and try to find solutions for this problem. The question is if this can be seen as Israel's way to become a secular state.

This article deals with the question what can be understood under secularization and especially if it can be transferred to the case of Israel. It will follow the classification of Casanova to consider the question if Israel is on the way to become a secular state. Furthermore the article explore the impact of this process on the meaning of national identity under the question if there could exist an Israel without a strong connection to Judaism. At the end it will be concluded that parts of the society are on the way to becoming secular, but resistance by orthodox movements and an increasing nationalism especially ethnic or religious nationalism are jeopardizing the developments to a secular and more equal Israel.

\section{Rethinking Secularism and Secularization}

Secularization as process and secularism as theory of the process are debatable terms and it can be asked what these terms mean. Secularization and secularism can be seen as the theory and process of the separation between religion and state, nevertheless there are different positions how this kind of separation should be and what separation means concretely. Besides this secularization is a product of the French Revolution and the Enlightenment, so secularization is a part of European history. This is a crucial fact by talking about secularization in another state with different historical context.

Secularism can be seen as the theory of the process of secularization, but moreover secularism appeared as an ideology. Secularism assumes that state and religion are strictly separated from each other. Secularism got a synonym for the absence of religion by which neutrality of the state freedom and equality guaranteed. However secularism is not like laicism strictly against religion, moreover political secularism sees religion as a moral institution which can provide the ethical cohesion (Casanova, 2009).

Secularism as an ideology is ongoing with secularization as process. Both concepts are controversial. On the one hand secularism is a western product of history, in reverse it can be asked if secularization as description of this process can adapted easily to another culture with different historical background. On the other hand under the debate of a post-secular age has been discussed if religion and his impact increasing again in Europe (Habermas, 2005).

Secularization describes the process of separation of state and religion, but there are different opinions how religion and state needs to be separated in the understanding of secularization. Sommerville (1998) states that secularization means the separation of religious activity from the remaining social occurrence, so to live in a secular society also matters to act under the secular law, nevertheless it is not impossible to be religious in this context.

For Böckenförde (2007), a sign of a secular state is to be completely separated from religion without any impact on each other. Religion can still develop freely, but a secular state provides the border for the public good. A secular state creates a room for the religion but it does not care about their retention. Nevertheless Böckenförde ask also if religion can be in a secular state a foundation of values for the society.

Chaves (1994) sees in secularization the declining of religious authority. He pointed out three different stages of secularization: First the separation between religion and state as a social process of laicism; second the internal secularization by which religious institutions moving to the secular world; and thirdly the end of 
individual believes and praise through not taking part in religious actions. But he sees secularization as a cycle, in which religion and secularization alternate to be strong and weak.

Also Casanova (2009; 2013) divides secularization in three different stages: First secularization as a historical process, whereby the religious and the secular sphere are getting separated and turning away from the religious institutions; second the end of religious believing; and thirdly the privatization of religion. Especially in Europe it seems that secularization means to leave religion behind and to get emancipated from this ancient relict. But Casanova explored also that most European countries defined themselves as secular without being really free from religion. Therefore he is asking, if secularism as theory can be found in reality or if this debate is moreover about the freedom of religion in democracies.

Under the debate about post-secularism, Casanova (2013) also concluded that a real secularism cannot be seen in most European societies, because of the still existing strong bond between religion and states. Churches have still an essential impact on politics in the European countries and often despite the separation between state and religion, religious communities are financed by the state. So he also follows Habermas (2005) in the question if secularization as process of separation proceeded or if this can be seen as historical process which underlies a cycle of increasing and decreasing. He states that Europe is becoming more religious again, because rituals and myth has an important impact on the identity. Post-secular states have the possibility for coexisting of religions and secularization, because of this ongoing process in which both mentalities are alternating prevailing could be creating an acceptance on both sides.

\section{Secularization in Israel}

There is no shortcut to resolving the religious problem in Israel. It exists because modernity has made for a wholly paradoxical situation in Jewish life- the intensive rise of Jewish nationalism, which has led to the creation of the Jewish state, and the simultaneous erosion of religion. (Yaron, 1976, p. 89)

Yaron states in this quote however religion is decreasing in Israel the religious problems cannot be solved, because of the strong bond between religion, nationalism and state. Indeed since the founding of Israel in 1948 this strong bond was emphasized also as national identity. This strong bond is an important aspect of Judaism, although this connection alternates in his strength. Judaism is not only a religion, but rather a concept of a nation and a cultural background.

Nevertheless, secularism or the distinguished reflections about religion were also crucial parts of the Jewish history. The Haskalah and the Zionist movement had an important impact on a secular Jewish idea. Especially the main Zionist movement of Theodor Herzl was a socialistic and secular national movement of the Jewish people in Europe. However, Herzl and his allies have been aware of the importance of Judaism as a national bond when this movement got stronger and was able to formulate political aims. They were certain that a new state, which did not exist for thousands of years, needed a common culture and historical memory to unite the plural society.

Also Ben-Gurion, the first Prime Minister of Israel, was aware of this fact, especially shortly after the Shoa. Although Ben-Gurion was not interested in a strong emphasis on religion, he was aware that the new state with a pluralistic society can only be build up with the help of all religious movements. To establish the state and because of the national cohesion Ben-Gurion needed particularly the support from the orthodox side; therefore he made with the status quo in 1947 an agreement to get the support of the orthodox side. In this letter from Ben-Gurion to the orthodox party Agudat Yisrael he promised to take care of the religious issues and to 
implement the Halacha as national legislation (Cohen \& Susser, 1996). Till this day the religious status quo has an important impact on the daily life of the population in Israel. But globalization, modernization and individuality get more essential and have an influence on Israeli society. Nevertheless there is still a strong relation between state, religion and nationhood but parts of the society rethinking this strong connection.

\section{Separation as Historical Process}

The historical process of separation between the secular and religious world can be shown by the political and legal situation in Israel. Legally since the letter from Ben-Gurion to the Agudat Israel in 1947 the religious status quo has been established but not changed yet. The status quo is in discussion, because the majority wants to change the restrictions by the status quo, but especially the orthodox population is strictly against it.

In the status quo it is written that rabbinical courts deal with questions of the personal status. Israel has still no possibility for a civil marriage, but people are not satisfied with the orthodox fulfillment of marriage. Beside this, a lot of couples have problems getting married, because of their different belonging to a Jewish rabbinate or the problem of being recognized as a full Jew. To obtain a full citizenship under the law of return, it is necessary to be recognized as a Jew under the orthodox definition. Often, The High Courts of Justice need to recognize marriages which have been fulfilled in a different country. Same-sex marriages are also not possible to fulfill legally. The only option is here also a marriage abroad and recognition by the High court of Justice (Ben-Porat, 2013a; Lis, 2015). Actually, the NGO Hiddush speaks from 20\% of the marriages are fulfilled abroad. Sixty six million Israeli Jews are prevented to get married, because of the current legislation. Seventy percent of the secular Israeli would have a secular marriage, if this would be possible (Jewish Telegraphic Agency, 2016).

The same problems exist also for divorces which can be only fulfilled by the rabbinates. The NGO Mavoi Satum found out, that $75 \%$ of the sample is for a civil divorce. Especially the weak position of the women in a case of a divorce seems to be here the problem (Bagno, 2015). A few NGO's and LGBT groups are fighting for the civil marriage and divorce. LGBT groups hope with a civil marriage the recognition of the same-sex marriage. But the implementation of a civil marriage has failed until now, because of the political composition of the Knesset. Beside this religious parties try to prevent with legislative sanctions the work of the NGO's and LGBT groups. The lack of a civil marriage is criticized as undemocratic actions and disobeying human rights.

Observance of the Kashrut, so serving kosher food in public buildings, is also under the control of the rabbinates. But also kosher certifications for restaurants are under the control of the rabbinates. Observing the Kashrut has two different problems. On the one hand a lot of immigrants are not willing to live under the restrictions of the Kashrut. Especially the consumption of pork is a cultural delicacy for them, but the breeding of pork is forbidden and importing complicated (Ben-Porat, 2013b). On the other hand restaurant owners are not satisfied, that the release of Kashrut certifications is under the orthodox control, because they reproach the orthodox system to be corrupt. Therefore they try to provide beside the orthodox offer an own Kashrut certification system (Yaron, 2015).

Shabbat was mentioned in the status quo as the day of rest. Shabbat regulations includes a general prohibition of employment, closing of all public buildings, closing of the public transport system and it is forbidden to run cinemas or theaters. But the Shabbat regulation is under municipal law. In the past, regions and cities with a high secular population relaxed the covenants (Morgenstern, 1990). Also globalization had an important influence on the question of running business on Shabbat. The increasingly economization and 
integration into international markets made it important to liberalize Shabbat regulations for the companies. Beside this under the impression of a consumer society, there is the demand of shopping possibilities also on Shabbat and especially younger Israeli citizens are against strict Shabbat rules (Ben-Porat, 2013b).

Because of the impact on the daily lives, possibilities to change the status quo have been often discussed in public. Discussions are about opening times of shopping malls on Shabbat, closing of the public transportation system or civil marriage. The last debate was about holding soccer matches on Shabbat and even this question shows how religion can influence the daily lives in Israel. Whereas at the end soccer matches could not forbid especially in the professional league because of negative influence for the leagues and broadcast rights. But lower leagues are compelled not to play on the day of rest (Haaretz, 2015; Haaretz, 2016).

Also religious questions, if women should be allowed to pray at the Western Wall or who is able to go to a public ritual bath the Mikve which are running under the rabbinates, were discussed in public. Particularly these questions expose, that also religious issues are now in public debate. The orthodoxy is losing his hegemonic position and decisions or religious issues are increasing in public debate especially if they are dealing with the question of equality between sexes. The orthodox monopoly is decreasing, because on the one hand religious groups are searching for new religious perspectives and on the other hand secular people are asking for possibilities alternatives to the orthodox system (Pfeffer, 2016).

Nevertheless religious rites are crucial for Israel, because of the ethnical and religious belonging of the population and otherwise orthodox offers are subsidized by the state. A couple of NGO's, like Tzohar or Itim, try to provide an alternative system to the orthodox monopoly. Tzohar is trying to provide a lot of offers in religious matters beside the orthodox system, for example they offer more open and unconventional marriages for secular Jews. Itim offers information about alternatives forms of religious rites like secular Bar Mitzvah. Nevertheless the orthodox parties are trying to prevent these actions with legally sanctioning to hold the orthodox monopoly in this issue (Ferziger, 2008).

To have a choice, people are asking for alternatives than the orthodox offers. The rabbinical hegemony is under pressure and therefore the orthodox monopoly begins to vanish because of process of change in society and economy. Especially in matters of personal status the society begins to ask, if there could be other options than the orthodox monopoly. This process is a grassroots movement from the middle of the society and cannot provide from political side, which can be expose with the results of the surveys but also with the importance of organizations like Itim or Tzohar.

In the current situation, changes seem to be possible merely with pressure by society. Israeli society is divided into different cleavages, which run along the ethnical and religious belongings. These cleavages have also a crucial impact on the political system, because it is characterized by plurality which leads to a variety of parties in the political system (Ben-Rafael, 2008). Each ethnicity, political or religious movement has its own party and leads often to changes in the political system. The complex Party system and the minor election threshold promote also young parties to get in a short time seats in Parliament. Coalition can be only found with a high number of coalition partners and religious parties often tip the scales, because they are necessary to form a coalition. With this understanding they are able to make pressure on leading political parties. These circumstances cause a political deadlock, which leads to a heavily changeable political system. Additionally the conflict with the Palestinian people and the fear of terrorism keep politics under pressure to find a solution which all sides can accept. This main conflict is also a reason for the stagnation of political possibilities to change the current situation, because it seems that this is an overarching topic which appears in all discussions. 
On the one hand, up to date the religious status quo is leading the state and religious parties seems to be more important than before, but on the other hand parts of the society are unwilling to accept the dominance of orthodox rabbinates anymore. People want to have a possibility of choice, but currently the political deadlock avoids any kind of changes in the system which runs now since the establishing of the state.

\section{End of Religious Belief}

A decline of religious belief in Israel can be seen by studying the societal situation. Currently $40 \%$ of the Israeli define themselves as secular, $23 \%$ as traditional, $10 \%$ as religious, and $8 \%$ as ultra-orthodox (Pew Research Center, 2016). This cleavage has an important impact on the choice of friendships, marriage or political topics like the weighing between Halacha and democracy. This division is in Judaism deeply rooted and a question of different religious rites and culture. People remain life-long in their religious movement, because changes between the groups are not common.

People are not atheist; however the majority define themselves as secular. The differences between these movements are in the definition of religion, the various rituals and the importance of observing the Halacha. As more people are religious as more they favoring influence by the Halacha and less by governmental regulations (Pew Research Center, 2016).

Judaism has still an important impact on the life of secular people, but moreover in the meaning of moral value, tradition and culture of the state Israel. Often secular people are more open about relaxing covenants of the status quo or to abolish it generally. Although secular people are convinced that religion is not important in their life, almost all of the Jewish population in Israel, including secular people, practices rituals on the highest Jewish holidays. For example, 90\% of the Jewish population in Israel observe Seder evening on Passover, 82\% are lightening candles at Chanukah (Keissar-Sugarman, 2012). As a belief system religion is not important anymore for secular people, moreover religion is now seen in the context of civil religion in which Judaism is part of the public understanding of the state and provides a shared history and tradition. As a sign of national belonging also secular people participate in religious rites in the meaning of Judaism as shared national culture and tradition. Currently secular people are in majority and try to change the situation of the status quo or to relax the restrictions by orthodox rabbinates. Democracy has a higher importance for secular people therefore they also favor repression of the Halacha and support the separation between state and religion (Pew Research Center, 2016).

\section{Privatization of Religion}

Judaism represents the national identity; hence privatization of religion in Israel cannot be seen. Religion is seeable in public, because national feelings are defined over religion and were emphasis in public. Ninety-three percent of the Jewish population in Israel is proud of their Jewish identity. Eighty-eight percent are proud to belong to Jewish population (Pew Research Center, 2016). But 41\% define themselves as Israeli and $51 \%$ as Jewish (Keissar-Sugarmen, 2012). The distinctions are in the different interpretations what a Jewish identity means.

It is a matter of national identity to be Jewish; thereby Judaism appears as bond and as cleavage. Especially in the beginning of the state, religion has a major role as bond between the different ethnic groups and religious affiliations. Nowadays religion seems to be a relic from ancient times, which divides the society in different groups. There is an inequality between the different groups like in governmental support or 
possibilities in society. Inequalities are not only between the different religious affiliations but also between ethnicity like Ashkenazi Jews and Mizrahi Jews. Mizrahi Jews, originally rooted in Spain or Middle East, feel often more discriminated by the society and politics than Ashkenazi Jews, because Ashkenazi Jews founded the state and supported especially in the beginning more traditions of their ethnicity. Also in important state positions Ashkenazi Jews are in majority (Pew Research Center, 2016).

Because of the strong emphasis on Judaism in public and legal framework, it is in discussion if this can still be seen under democratic principles. Smooha (2002) or Yiftachel (2006) conclude under this circumstances this can be seen as ethnic democracy. The phenomenon is more associated with one ethnicity including their tradition and therefore cannot provide the same rights for all citizens. This can be also observed in Israel. Even in public Judaism is providing the core symbols and values of the civil religion, in which equal rights for all citizens cannot provide, because of the strong emphasis on Judaism as national identity.

However, Israel has not an official religion in state, since 1985 it is written in the basic law that the state Israel is for the Jewish population without being explicit a Jewish state (Wolffsohn, 2007). Also the current debate about a constitution expose how the religious question is approached by the politicians, which had favor in the first draft a stronger emphasis on Judaism as state religion. Especially concerning the tense situation with Palestinian people it is mentioned that a strong emphasis on religion would be important (Harkov, 2015).

Under Israeli nationalism it is understood as a Jewish nationalism, so a strong emphasis on religion in a national meaning. However this leads to exclusion in society and civil religion of people who are not Jewish or not from an orthodox perspective. This problematic lack of democracy seems to be in nature of the state Israel and it is caused by the strong bond between Judaism as religion and nation (Berent, 2010). Religion is often used by politicians for the legitimation of political actions and is seeable in public in form of public symbols, religious celebrations or even special religious districts. In the national understanding presenting of religion as part of the historical tradition and common culture is accepted and supported by the population. However a decrease can be seen in people who believe in Judaism as religion, but withdraw of religion into private spheres cannot be seen; moreover Judaism is a crucial part of the national understanding.

\section{Secularization: Curse or Blessing}

Uri Ram (2008) said in his article, Why Secularism Fails, that secularization in Israel is not possible. By following Casanovas classification of secularization he determined that Israel has fulfilled the secularization only in the matter of the decline of belief, but there is no privatization of religion and differentiation of the secular spheres. He found out that mostly the problem of implementation of secularization is caused by the strong emphasis on religion as national identity. Ram said in his article that even the secular movement of Zionism has supported religion: "Zionism is 'secularism with a skullcap in the pocket”" (Ram, 2008, p. 71). Currently Israel is not a secular state, but different to the statement of Ram it cannot conclude that secularization needs to fail. However the possibilities for political changes are decreasing, but the movements in society should be noticed as part of a secularization process.

Since the founding of the state ethnicities were more important than civil terms, but even before the strong bond between religion and state had a long tradition in Judaism because this bond as God's chosen people is a biblical term. Leadership, religion and nationhood were already in times of Moses crucial and got a symbol for Judaism. Also in time of Diaspora Judaism was not only seen as religion but rather as a culture identity of a nation. During the British Mandate, the legal situation with different rabbinates, who decide about personal 
status matters, was common practice. The adoption of this legal system in the new state can be seen as a dichotomous process.

Another problem to transfer the idea of secularization is the historical process behind it. Secularization is a western product of the enlightenment and French revolution. In contrast in all countries of the Middle East religion is important in society, politics and as national identity. The intensity of the influence on the state has also an impact on the democratic character of the state, but in all states religion is part of the shared culture.

Currently Israel is not a secular state. Religion and state are not separated from each other because of the status quo. But Israel is reaching a crossroad. On the one hand international markets and globalization demand flexibility of actions, however religious restrictions are counterproductive. Additionally globalization and modernization provide a new perspective of lifestyle, in which individualization is searching for alternative possibilities than the orthodox offers. But on the other hand the religious ties are important for Israel, because religion is crucial for the national identity. So parts of Israeli society are on the way to becoming secular, but moreover this movement can merely supported from the citizens because of the deadlock in political system.

The strong emphasis on religious and ethnical matters in Israel causes inequalities between the different groups in society. Beside the religious affiliations like secular or orthodox Jew, this division is also between the different ethnicities like Ashkenazi or Mizrahi Jews and Arab population. Each group has different opportunities and possibilities of impact on the society and politics. Especially dealing with the Arab population leads to the question if Israel can still be seen as liberal democracy or ethnic democracy. This circumstances leads to the question if secularization could solve this problem. Secularization as a real division between religion and state, so the abolishment of the religious status quo, could provide equality under the Jewish religious groups. If all matters of personal status and also the allocation of kosher certifications would be under state supervision, there would be no inequality between the different rabbinates anymore. Rabbinates would not have the same influence on the personal lives of the people like now, whether in question of civil marriage or citizenship.

The question is how the national identity will appear when Israel is on the way to become secular. Especially when people are losing their religious ties because they do not believe anymore, how religion will be replaced and what will be the core values of the bond in the state. Currently secularism and secularization provide an increase of a strong national emphasis. Judaism is not observing as a belief system but rather as part of the national identity and also symbols and rituals are visible in public as civil religion.

However this public debate about secularization jeopardizes the society. Orthodox movements are not satisfied to lose their influence on state and society and they try to hold the status quo. In the last time also religious matters appeared in the public debate, like if women should be allowed to pray equally like men at the western wall or if non-orthodox conversions should be also recognized in Israel. The religious establishment is under critique how the current debate is explored, because it has evoked the question if religious beliefs and principles are still contemporary especially in the question of equality between men and women (Maltz, 2016; Pfeffer, 2016). Orthodox reactions are often the same, by fighting against possible changes. Often because they are able to tip the scale in government they are successful with their opposing view, which prevent the process of secularization.

Beside this, the other problem about secularization in Israel is in the understanding of secularization as a complete division between state and religion which can be confused with laicism. It seems that secularization forbid religion in public and displaces religion into private sphere. Therefore religious people can have the 
feeling, that their religion has no future in a secular state and take this as reason to fight against this process (Maltz, 2016).

In special cases this could also lead to religious nationalism as a variety of nationalism. In this case of a strong emphasis on nationalism with religion as a foundation of values, inequality between believer and non-believer or another religion is implicit. Religious nationalism leads to justifying political actions as part of the religious idea. Not uncommonly religious nationalism entails the risk of fundamentalism and violence (Friedland, 2001). Israel must deal not only with threat by the Arab population but also with violence by the religious fundamentals groups, which was already shown in the stabbing attack on the Jerusalem gay parade or the assault of Yitzhak Rabin.

Secularization has the capability to handle the inequality between the different religious movements and could ease the situation with the Arab population if all citizens would be equal under the law and would have the same possibilities. Nevertheless an increasing of nationalism could also provide a strong ethnocentrism as distinctions from other ethnicities and religions. This could strengthen Israeli ethnic democracy as consequence of a strong religious-ethnical emphasis in national identity and would by implication jeopardize equality between the different groups.

\section{Conclusions}

To sum up secularization in Israel seems to be contradictory because of the importance of Judaism in the state. But currently the society is changing in Israel and parts of Israeli society are on the way to become secular. This process is concerning only a part of the society and the special political situation leads to the problem that this process can merely initiate by the population. Currently it is decreasing that people believes and religion as a belief system is losing his importance. A huge majority of the people would also favor a clear division between religion and state. Currently this cannot be implementing, because of the deadlock in the political system. The pluralistic party system, huge party numbers in coalitions and the ongoing threat of terrorism prevent changes in the political situation and about big political issues. Often the Supreme Court is the last opportunity to circumvent the status quo. The problem is, that people are not voting in concern of secularization, moreover security reasons and shortly upcoming problems are more in focus of people's choice. Therefore more conservative and nationalistic parties are elected into the Knesset, which need the support by the religious side.

Nevertheless Israeli society is becoming increasingly secular, however it is discussable what secularization means. Also in western countries it is debatable, if states which declare themselves as secular can really understand as secular under the theoretical concept. A strong emphasis on the religious history would be common as national identity, even if Israel would decide to divide religion and state. If secularization is not understood as an absence of religion but rather as a division of the religious and secular sphere, it is clear that in Israel religion will be part of the national identity as historical memory, tradition and base of values. But as a result of the secularization Israel would have the possibilities to equalize the society, because currently Israeli society is divided into the different ethnicities and religious movements which are unequal treat in society and by the law. Nevertheless ethnical and religious nationalism are the jeopardies of secularization, because of their tendency to provide ethnocentrism and therefore inequality.

Israeli society is in a process of change. Although the secular population is growing, because of the importance of Judaism as national identity secular people would not become atheist. Furthermore a real debate 
about the theoretical framework of secularism is not present in Israeli public, beside a few opinions of Israeli intellectuals, so that a theoretical debate about the understanding of secularization as process is not possible. Secularization can be seen more like a consecutive process of globalization, westernization and demand for individual choices. As a real possibility of individual choices, people are trying to find alternatives to the orthodox offerings. However the resistance by the orthodox movements is huge, because religious fundamentalists and the orthodox population are strictly against changes in the status quo. At least only future developments can expose if secular and liberal forces will be strong enough to change the current situation or if religious movements and their argumentations for a strong emphasis on a Jewish national identity in Israel are even stronger.

\section{References}

Bagno, Y. (2015, January 11). NGO petitions High Court to allow same-sex marriage in Israel. The Jerusalem Post. Retrieved from http://www.jpost.com/Israel-News/NGO-The-Aguda-petitions-Supreme-Court-to-allow-same-sex-marriage-Israel-4317 33

Ben-Rafael, E. (2008). The faces of religiosity in Israel: Cleavages or continuum? Israel Studies, 13(3), 89-113.

Ben-Porat, G. (2013a). Are we there yet? Religion, secularization and liberal democracy in Israel. Mediterranean Politics, 18(2), 242-258.

Ben-Porat, G. (2013b). Between state and synagogue: The secularization of Contemporary Israel. Cambridge: Cambridge University Press.

Berent, M. (2010). The ethnic democracy debate: how unique is Israel? Nations and Nationalism, 16(4), 657-674.

Böckenförde, E. W. (2007). Der säkularisierte Staat: Sein Charakter, seine Rechtfertigung und seine Probleme. München: Carl Friedrich von Siemensstiftung.

Casanova, J. (2009). The secular and secularisms. Social Research, 76(4), 1049-1066.

Casanova, J. (2013). Is secularization global? In G. Buss \& M. Luber (Eds.), Weltkirche und Mission Band 3 Neue Räume Öffnen: Mission und Säkularisierungen weltweit, (pp. 69-81). Regensburg: Verlag Friedrich Pustet.

Chaves, M. (1994). Secularization as declining religious authority. Social Forces March, 72(3), 749-774.

Cohen, A., \& Susser, B. (1996). From accommodation to decision: Transformations in Israel's religio-political life. Journal of Church and State, 38(4), 817-839.

Ferziger, A. S. (2008). Religion for the secular. Journal of Modern Jewish Studies, 7(1), 67-90.

Friedland, R. (2001). Religious nationalism and the problem of collective representation. Annual Reviews Sociologie, 27, 125-152.

Haaretz. (2015, September 2). Israel’s Soccer Chief: All local matches will be canceled unless Shabbat permit granted. Haaretz. Retrieved from http://www.haaretz.com/news/israel/1.674207

Haaretz. (2016, April 5). Despite religious concerns, Israel to legalize soccer games on Shabbat. Haaretz. Retrieved from http://www.haaretz.com/israel-news/sports/.premium-1.712500

Habermas, J. (2005). Zwischen Naturalismus und Religion: Philosophische Aufsätze. Frankfurt am Main: Suhrkamp.

Harkov, L. (2015, October 22). MK Aviv Dichter revives Jewish State legislation. The Jerusalem Post. Retrieved from http://www.jpost.com/Israel-News/Politics-And-Diplomacy/Controversial-NGO-bill-to-go-to-first-Knesset-vote-442609

Jewish Telegraphic Agency. (2016, April 12). Report: 660,000 Jews can’t legally marry in Israel. Haaretz. Retrieved from http://www.haaretz.com/israel-news/1.696971

Keissar-Sugarmen, A. (2012). A portrait of Israeli Jews: Beliefs, observance, and values of Israeli Jews, 2009. Retrieved from http://en.idi.org.il/media/1351622/GuttmanAviChaiReport2012_EngFinal.pdf

Lis, J. (2015, December 31). Ministers likely to reject civil marriage bill under religious pressure. Haaretz. Retrieved from http://www.haaretz.com/israel-news/.premium-1.694839

Maltz, J. (2016, May 25). High Court opens door to recognition of non-orthodox conversions in Israel. Haaretz. Retrieved from http://www.haaretz.com/israel-news/.premium-1.721474

Morgenstern, M. (1990). Religion und Politik in Israel- Tendenzen und Hintergründe. In M. Morgenstern (Ed.), Schriftenreihe des Deutsch-Israelischen Arbeitskreises für Frieden im Nahen Osten e.V Bd. 18. Kampf um den Staat: Religion und Nationalismus in Israel (pp.11-137). Frankfurt am Main: Haag + Herchen. 
Pew Research Center. (2016). Israel's religiously divided society: Deep gulfs among Jews, as well as between Jews and Arabs, over political values and religion's role in public life.

Pfeffer, A. (2016, April 8). Goodbye to the reign of the rabbinate, Hello to a new era of Judaism. Haaretz. Retrieved from http://www.haaretz.com/opinion/.premium-1.713385

Ram, U. (2008). Why secularism fails? Secular nationalism and religious revivalism in Israel. International Journal of Politics, Culture, and Society, 21(1-4), 57-73.

Smooha, S. (2002). The model of ethnic democracy: Israel as a Jewish and democratic state. Nations and Nationalism, 8(4), 475-503.

Sommerville, J. (1998). Secular society/religious population: Our tacit rules for using the term "Secularization”. Journal for the Scientific Study of Religion, 37(2), 249-253.

Wolffsohn, M. (2007). Israel: Geschichte, Politik, Gesellschaft, Wirtschaft. Wiesbaden: VS, Verlag für Sozialwissenschaften.

Yaron, Z. (1976). Religion in Israel. American Jewish Year Book, 1976, 41-90.

Yaron, G. (2015, August 7). Das Koscher-Zertifikat ist selbst nicht ganz koscher. Die Welt. Retrieved from http://www.welt.de/politik/ausland/article144936205/Das-Koscher-Zertifikat-ist-selbst-nicht-ganz-koscher.html

Yiftachel, O. (2006). Ethnocracy: Land and identity politics in Israel/Palestine. Philadelphia: University of Pennsylvania Press. 